\title{
UJI MUTU TEPUNG BIJI DURIAN SEBAGAI BAHAN PANGAN ALTERNATIF BERDASARKAN KADAR AIR DAN KADAR ABU SERTA CEMARAN MIKROBA
}

\author{
Devita Yudhayanti ${ }^{1}$, Mila Restiani ${ }^{2}$ \\ ${ }^{1,2)}$ Akafarma Sunan Giri Ponorogo, J1. Batoro Katong 32 Ponorogo \\ e-mail: ${ }^{1)}$ devita.akafarma@gmail.com
}

\begin{abstract}
Abstrak
Latar belakang: Durian (Durio zibethinus murr) adalah salah satu buah yang sangat populer di Indonesia.Biji durian mentah dapat diolah dalam bentuk tepung dan dimanfaatkan sebagai bahan pengganti sebagai sumber karbohidrat, karena dalam biji durian terdapat karbohidrat sebanyak 43,6 gram per 100 gram.Tujuan: untuk membuat tepung biji durian dan dilakukan uji untuk mengetahui organoleptik, kadar air, kadar abu dan cemaran mikroba berdasarkan Standar Nasional Indonesia No. 3751 tahun 2009 diantaranya organoleptik, kadar air $\leq 14,5 \%$, kadar abu $\leq 0,70 \%$, ALT $\leq 10^{6}$ dan AKK $\leq$ $10^{4}$. Metode: kadar air dengan metode gravimetri, kadar abu dengan metode gravimetri, uji cemaran mikroba dengan metode ALT sebanyak 25-250 koloni/gram yang dihitung dan AKK sebanyak 10-150 koloni/gram yang dihitung. Hasil:.P1 memiliki hasil uji organoleptik bentuk serbuk, bau khas, warna coklat, kadar air 8,594\%, kadar abu 3,693\%, ALT 135 x 102 koloni/gram, AKK 0 koloni/gram. P2 memiliki hasil uji organoleptik bentuk serbuk, bau khas, warna coklat terang, kadar air 8,598\%, kadar abu 3,473\%, ALT 9,5 x $10^{1} \mathrm{koloni} /$ gram, AKK $28 \times 10^{2} \mathrm{koloni} /$ gram. P3 memiliki hasil uji organoleptik bentuk serbuk, bau khas, warna coklat, kadar air 6,782\%, kadar abu 3,527\%, ALT 194 x $10^{1}$ koloni/gram, AKK $11 \times 10^{1}$ koloni/gram.Hasil uji kadar air $<14,5 \%$, hasil uji ALT $<10^{6}$ dan hasil uji $<10^{4}$, sedangkan hasil kadar abu $>0,70 \%$.Simpulan dan saran: Dari hasil pengujian mutu dapat dinyatakan bahwa tepung biji durian memenuhi persyaratan mutu dari Standar Nasional Indonesia No. 3751 tahun 2009 kecuali kadar abu.
\end{abstract}

Kata Kunci : tepung biji durian, organoleptik, kadar air, kadar abu, ALT, AKK

\begin{abstract}
Background: Durian (Durio zibethinus murr) is a fruit that is very popular in Indonesia.Raw durian seeds can be processed in the form of flour and used as a substitute material as a source of carbohydrates, durian seeds because in there as much as 43.6 grams of carbohydrates per 100 grams.Objectives: to make a durian seed flour and do a test to find out organoleptic, moisture content, ash and microbial impurities levels based on National standard of Indonesia No. 3751 year 2009 including organoleptic, moisture content $\leq 14.5 \%$, ash content $\leq 0.70 \%$, ALT $\leq 106$ and $104 \leq$ AKK.Methods: gravimetric water content by the method of gray levels, gravimetric methods, test of microbial impurities with ALT method as much as 25-250 colonies $/ g$ are calculated and AKK 10-150 as many colonies/g are calculated. Results: P1 has organoleptic test results in powder form, characteristic odor, brown color, water content of $8.594 \%$, ash content of $3.693 \%$, ALT $135 \times 102$ colonies / gram, AKK 0 colonies / gram. P2 has organoleptic test results in powder form, characteristic odor, light brown color, moisture content $8.598 \%$, ash content 3.473\%, ALT $9.5 \times 101$ colony / gram, AKK $28 \times 102$ colony / gram. P3 has organoleptic test results in powder form, characteristic odor, brown color, water content 6,782\%, ash content 3,527\%, ALT $194 \times 101$ colony / gram, AKK $11 \times 101$ colony / gram. Water content test results $<14.5 \%$, ALT test results $<106$ and test results <104, while ash content results $>0.70 \%$. Conclusions and suggestions: From the results of quality testing it can be stated that durian seed flour meets the quality requirements of Indonesian National Standard No. 3751 in 2009 except ash content.
\end{abstract}

Keywords : durian seed flour, organoleptic, moisture content, ash content, ALT, AKK 


\section{PENDAHULUAN}

Durian (Durio zibethinus murr) adalah salah satu buah yang sangat populer di Indonesia. Buah dengan julukan The King of fruits ini termasuk dalam famili Bombacaceae dan banyak ditemukan di daerah tropis (Djaeni, 2010). Selama ini, bagian buah durian yang lebih umum dikonsumsi adalah bagian salut buah atau dagingnya. Biji durian mentah dapat diolah dalam bentuk tepung dan dimanfaatkan sebagai bahan pengganti sebagai sumber karbohidrat, karena dalam biji durian terdarat karbohidrat sebanyak 43,6 gram per 100 gram (Zuhri, 2015).Biji durian apabila dibuat menjadi tepung akan menghasilkan tepung yang berwarna putih kekuningan. Pembuatan tepung ini semua komponen yang terkandung dalam bahan pangan dipertahankan keberadaannya, kecuali air karena untuk meminimalisir terjadinya pertumbuhan bakteri dan untuk ketahanan lebih lama dalam penyimpanannya.

Nathanael (2016) menyatakan dalam penelitiannya bahwa, dengan penambahan tepung biji durian berpengaruh nyata terhadap kadar air, kadar abu, kadar protein, kadar karbohidrat, daya pengembangan dan penilaian sensori pada roti tawar, untuk penambahan tepung biji durian yang lebih tinggi memberikan perbedaan yang nyata yaitu kadar protein semakin tinggi dan kadar lemak pada roti tawar menjadi lebih kecil. Sebelum memanfaatkan tepung biji durian menjadi produk makanan tentunya tepung biji durian harus memenuhi uji mutu tepung diantaranya uji organoleptis, benda-benda asing, serangga dalam bentuk potongan-potongan yang tampak, kehalusan, kadar air, kadar abu, kadar protein, keasaman, falling number, besi, seng, vitamin, cemaran logam, cemaran arsen dan cemaran mikroba (SNI, 2009).

Berdasarkan uraian di atas dan beberapa penelitian yang telah dilakukan tentang pemanfaatan biji durian dalam bentuk tepung, peneliti tertarik untuk membuat tepung biji durian dan melakukan Uji Mutu Tepung Biji Durian Sebagai Bahan Pangan Alternatif Berdasarkan Kadar Air Dan Kadar Abu Serta Cemaran Mikroba. Syarat pengujian pada penelitian ini mengacu pada syarat mutu tepung terigu Standar Nasional Indonesia (SNI) No. 3751-2009.

\section{METODE PENELITIAN}

Penelitian ini dilakukan pembuatan tepung biji durian. Kemudian dilakukan penelitian mengenai uji mutu tepung biji durian sesuai dengan persyaratan SNI 3751:2009, diantaranya uji organoleptik, uji kadar air, uji kadar abu, uji ALT, dan uji Kapang.

1. Pembuatan Tepung Biji Durian

Biji durian disortir basah dan kering. Lalu pemblansingan selama \pm 5 menit pada suhu $80^{\circ} \mathrm{C}$. Perendaman pada air kapur 10\% selama 1 jam, lalu dicuci. Potong kecil-kecil untuk pengeringan. Dikeringkan selama 3 hari, lalu oven pada suhu $100^{\circ} \mathrm{C}$ selama 20 menit. Diamkan hinggan dingin, lalu blender dan ayak. Proses diulangi pada hari yang berbeda. 
Vol. 1, No.2, Desember 2019, hal43-48

2. Uji Organoleptis

Diperiksa bentuk, bau dan warna sampel

3. Uji Kadar Air

Memanaskan krus porselen beserta tutupnya dengan oven pada suhu $(130 \pm 3)^{\circ} \mathrm{C}$. . Mendinginkan dalam desikator selama 30 menit dan menimbang bobotnya. Menimbang sampel sebanyak 2 gram ke dalam krus porselen yang telah diketahui bobotnya (W). Mengeringkan dalam oven dengan keadaan terbuka pada suhu $(130 \pm 3)^{\circ} \mathrm{C}$ selama 1 jam (satu jam setelah suhu $130^{\circ} \mathrm{C}$ ). Mendinginkan dalam desikator selama 30 menit dan menimbang hingga diperoleh bobot tetap (W1)

4. Uji Kadar Abu

Memijarkan cawan dalam tanur listrik pada suhu $(550 \pm 10){ }^{\circ} \mathrm{C}$, yang sebelumnya dipanaskan dahulu pada penangas listrik selama 1 jam. Mendinginkan dalam desikator selama 1 jam dan timbang (W1). Ditimbang 3-5 gram sampel kedalam sebuah cawan porselen yang sudah diketahu bobot kosongnya. Mengarangkan di atas penangas listrik, kemudian mengabukan dalam tanur listrik pada suhu maksimum $(550 \pm 10)^{\circ} \mathrm{C}$ sampai putih atau kelabu selama 5 sampai 8 jam (sesekali pintu tanur dibuka sedikit agar oksigen masuk). Dinginkan dalam desikator selama 30 menit lalu timbang. Diulangi hingga bobot konstan.

5. Uji ALT

Buat larutan induk, yaitu 25 gram sampel pada $225 \mathrm{ml}$ pepton $0,1 \%$. Sampel diencerkan hingga pengenceran $10^{6}$ menggunakan pepton $0,1 \%$. Lalu masukkan $1 \mathrm{ml}$ masing-masing pengenceran pada media NA. Inkubasi pada suhu $35-37^{\circ} \mathrm{C}$ selama $24-48$ jam dengan posisi dibalik. Untuk blanko, tambahkan pepton $0,1 \%$ pada media NA, lalu inkubasi Inkubasi pada suhu $35-37^{\circ} \mathrm{C}$ selama $24-48$ jam dengan posisi dibalik. Amati

6. Uji AKK

Buat pengenceran $10^{4}$ dari larutan induk. Masukkan masing-masing $1 \mathrm{ml}$ pengenceran dalam media SGA. Untuk blanko media, berisi SGA. Untuk blanko inkas, berisi media SGA dan $1 \mathrm{ml}$ pepton. Inkubasi semua pada suhu $25 \pm 1^{\circ} \mathrm{C}$ selama 5 hari.

\section{HASIL DAN PEMBAHASAN}

Pembuatan tepung biji durian dilakukan dengan tiga kali produksi. Produksi dilakukan dengan perlakuan, berat biji durian yang sama dan waktu yang berbeda. Biji durian setelah dikupas sebanyak 1200 gram menghasilkan 400 gram tepung biji durian. 
Vol. 1, No.2, Desember 2019, hal43-48

1. Hasil Uji Organoleptis

Tabel 1. Data Hasil Uji Organoleptis

\begin{tabular}{cccc}
\hline \multirow{2}{*}{ Sampel Produksi } & \multicolumn{3}{c}{ Hasil Uji Organoleptik } \\
\cline { 2 - 4 } & Bentuk & Bau & Warna \\
\hline 1 & Serbuk & Khas & Coklat \\
2 & Serbuk & Khas & Coklat terang \\
3 & Serbuk & Khas & Coklat \\
\hline
\end{tabular}

2. Hasil Uji Kadar Air

Tabel 2. Data Hasil Uji Kadar Air

\begin{tabular}{cccc}
\hline Sampel & Pengulangan & Kadar air (\%) & Rata-rata (\%) \\
\hline \multirow{3}{*}{ P1 } & a & 8,446 & \\
& b & 8,596 & 8,594 \\
& c & 8,741 & \\
P2 & a & 8,596 & \\
& b & 8,969 & 8,598 \\
& c & 8,500 & \\
P3 & a & 6,647 & \\
& b & 6,850 & 6,782 \\
\hline
\end{tabular}

3. Hasil Uji Kadar Abu

Tabel 3. Data Hasil Uji Kadar Abu

\begin{tabular}{cccc}
\hline Sampel & Pengulangan & Kadar abu (\%) & Rata-rata (\%) \\
\hline \multirow{3}{*}{ P1 } & a & 3,660 & \\
& b & 3,519 & 3,693 \\
& c & 3,899 & \\
P2 & a & 3,379 & \\
& b & 3,560 & 3,473 \\
& c & 3,480 & \\
P3 & a & 3,460 & 3,527 \\
& b & 3,560 & \\
\hline
\end{tabular}

4. Hasil Uji AKK

Tabel 4. Data Hasil Uji AKK

\begin{tabular}{|c|c|c|c|c|c|}
\hline \multirow{2}{*}{ Sp } & \multirow{2}{*}{ Pengenceran } & \multicolumn{2}{|c|}{ HASIL } & \multirow{2}{*}{\multicolumn{2}{|c|}{ Rata-rata koloni/gram }} \\
\hline & & Pengenceran 1 & Pengenceran 2 & & \\
\hline \multirow{4}{*}{ P1 } & $10^{1}$ & 0 & 0 & 0 & 0 \\
\hline & $10^{2}$ & 0 & 0 & 0 & 0 \\
\hline & $10^{3}$ & 0 & 0 & 0 & 0 \\
\hline & $10^{4}$ & 0 & 0 & 0 & 0 \\
\hline \multirow{4}{*}{$\mathrm{P} 2$} & $10^{1}$ & 1 & 1 & $\frac{1+1}{2}=1$ & $1 \times 10^{1}=10$ \\
\hline & $10^{2}$ & 28 & 0 & 28 & $28 \times 10^{2}=2800$ \\
\hline & $10^{3}$ & 2 & 0 & 2 & $2 \times 10^{3}=2000$ \\
\hline & $10^{4}$ & 0 & 0 & 0 & 0 \\
\hline \multirow{2}{*}{ P3 } & $10^{1}$ & 0 & 11 & 11 & $11 \times 10^{1}=110$ \\
\hline & $10^{2}$ & 0 & 1 & 1 & $1 \times 10^{2}=100$ \\
\hline
\end{tabular}


Vol. 1, No.2, Desember 2019, hal43-48

\begin{tabular}{ccccc}
$10^{3}$ & 0 & 0 & 0 & 0 \\
\hline $10^{4}$ & 0 & 0 & 0 & 0 \\
\hline
\end{tabular}

\section{Hasil Uji ALT}

\section{Tabel 5. Data Hasil Uji ALT}

\begin{tabular}{|c|c|c|c|c|c|}
\hline \multirow{2}{*}{$\mathrm{Sp}$} & \multirow{2}{*}{ Pengenceran } & \multicolumn{2}{|c|}{ Hasil pengulangan } & \multirow{2}{*}{\multicolumn{2}{|c|}{$\begin{array}{c}\text { Rata-rata } \\
\text { (koloni/gram) }\end{array}$}} \\
\hline & & 1 & 2 & & \\
\hline \multirow{6}{*}{ P1 } & $10^{1}$ & Spreader & Spreader & Spreader & - \\
\hline & $10^{2}$ & 143 & 121 & $\frac{143+121}{2}=135$ & $135 \times 10^{2}=13500$ \\
\hline & $10^{3}$ & 33 & 44 & $\frac{33+44}{2}=38,5$ & $38,5 \times 10^{3}=38500$ \\
\hline & $10^{4}$ & 0 & 1 & 1 & $1 \times 10^{4}=1000$ \\
\hline & $10^{5}$ & 0 & 0 & 0 & 0 \\
\hline & $10^{6}$ & 0 & 1 & 1 & $1 \times 10^{6}=100000$ \\
\hline \multirow{6}{*}{ P2 } & $10^{1}$ & 17 & 2 & $\frac{17+2}{2}=9,5$ & $9,5 \times 10^{1}=95$ \\
\hline & $10^{2}$ & 0 & 0 & 0 & 0 \\
\hline & $10^{3}$ & 0 & 0 & 0 & 0 \\
\hline & $10^{4}$ & 0 & 0 & 0 & 0 \\
\hline & $10^{5}$ & 0 & 0 & 0 & 0 \\
\hline & $10^{6}$ & 0 & 0 & 0 & 0 \\
\hline \multirow{6}{*}{ P3 } & $10^{1}$ & 204 & 184 & $\frac{204+184}{2}=194$ & $194 \times 10^{1}=1940$ \\
\hline & $10^{2}$ & 276 & 110 & $\frac{276+110}{2}=193$ & $193 \times 10^{2}=19300$ \\
\hline & $10^{3}$ & 53 & 62 & $\frac{53+62}{2}=57,5$ & $57,5 \times 10^{3}=57500$ \\
\hline & $10^{4}$ & 0 & 0 & 0 & 0 \\
\hline & $10^{5}$ & 0 & 0 & 0 & 0 \\
\hline & $10^{6}$ & 0 & 0 & 0 & 0 \\
\hline
\end{tabular}

Uji mutu tepung biji durian produksi 1, 2 dan 3 (P1, P2 dan P3) meliputi uji organoleptik, kadar air, kadar abu, dan cemaran mikroba.Uji kadar air tepung biji durian produksi 1, 2 dan 3 (P1, P2 dan P3)memenuhi persyaratan mutu tepung terigu SNI 3751:2009 karena kadar air yang diperoleh kurang dari 14,5\%.Uji kadar abupada produk tepung biji durian P1, P2 maupun P3 tidak memenuhi persyaratan mutu tepung terigu SNI 3751:2009, karena kadar abu yang diperoleh melebihi dari kadar maksimum yang telah ditentukan yaitu 0,70\%.Uji Angka Lempeng Total (ALT) produksi tepung biji durian 1, 2 dan 3 (P1, P2 dan P3)memenuhi persyaratan mutu tepung terigu SNI 3751:2009 karena dari ketiga sampel menunjukkan hasil yang masih ditoleransi dari batas maksimum yaitu 1 x $10^{6}$ koloni/gram. Uji Angka Kapang Khamir (AKK) produksi tepung biji durian 1, 2 dan 3 (P1, P2 dan $\mathrm{P} 3)$ memenuhi persyaratan mutu tepung terigu SNI 3751:2009 karena dari ketiga sampel menunjukkan hasil yang masih ditoleransi dari batas maksimum yaitu $1 \times 10^{4}$ koloni/gram. 
Vol. 1, No.2, Desember 2019, hal43-48

\section{SIMPULAN}

Berdasarkan hasil penelitian yang sudah dilakukan, dapat disimpulkan bahwa :

1. Uji organoleptis berbeda, dipengaruhi oleh pengeringan dibawah sinar matahari, juga karena faktor jenis biji durian yang diolah.

2. Uji Kadar air memenuhi syarat, yaitu kurang dari $14,5 \%$, dengan masing-masing kadar yaitu P1 8,594\%, P2 8,598\% dan P3 6,782\%

3. Kadar Abu yaitu P1 3,693\%, P2 3,473\% dan P3 3,527\%. Kadar abu tidak memenuhi syarat karena lebih dari $0,7 \%$

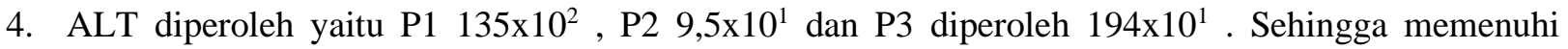
syarat, yaitu kurang dari $1 \times 10^{6}$

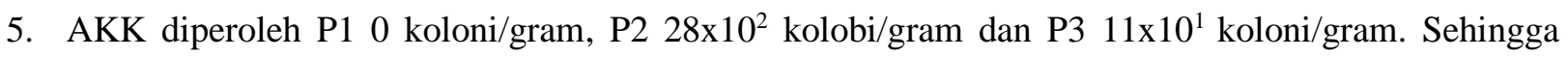
masih memenuhi syarat, yaitu kurang dari $1 \times 10^{4}$

\section{DAFTAR PUSTAKA}

Andarwulan, N, dkk. 2011. Analisis Pangan. In: Pengelolaan Data Analisis Pangan. Jakarta: Universitas Terbuka, pp. 1-41. ISBN 9789790112246

Badan Litbang Pertanian. 2013. AgroinovasI. Jakarta Selatan: Badan Penelitian Dan Pengembangan Pertanian

Djaeni, M dan A, Prasetyaningrum. 2010. Kelayakan Biji Durian Sebagai Bahan Pangan Alternatif: Aspek Nutrisi dan Tekno Ekonomi. Riptek Vol.4, No.II, Tahun 2010

Nathanael, S, R, dkk. 2016. Penambahan Tepung Biji Durian (Durio zibethinus) Dalam Pembuatan Roti Tawar. JOM Faperta Vol. 3 No. 2

Sistanto, dkk. 2017. Pemanfaatan Limbah Biji Durian (Durio zibethinus Murr) Sebagai Bahan Penstabil Es Krim Susu Sapi Perah. Jurnal Sain Peternakan Indonesia Vol. 12, No. 12017

USDA. 2018. Classification for Kingdom Plantae Down to Species Durio zibethinus Murray, (Online), (https://plants.usda.gov), diakses 8 Maret 2018

Wahyono. 2009. Karakteristik Edible Film Berbahan Dasar Kulit dan Pati Biji Durian (Durio sp) untuk Pengemasan Buah Strawberry. Skripsi Tidak Diterbitkan. Surakarta: UMS

Zuhri, M, dkk. 2015. Karakteristik Kimia dan Fungsional Tepung Biji Durian (Durio zibethinus Murr) Termodifikasi. Medan: USU Medan. J. Rekayasa Pangan dan Pert., Vol.3 No.2 Th.2015 